\title{
Areas of Reforming Housing and Utilities Sector in Current Environment on Example of Sakha Republic (Yakutia)
}

\author{
Mikhail P. Solomonov ${ }^{1}$ \\ Egor Grigorievich Egorov² \\ Stepan G. Turantaev ${ }^{3}$

\begin{abstract}
${ }^{1}$ Research Institute of Regional Economy of the North, North-Eastern Federal University in Yakutsk
Republic of Sakha (Yakutia), Russian Federation

${ }^{2}$ Doctor of Economics, Professor, Academician of the Academy of Science of the Sakha (Yakutia) Republic

Republic of Sakha (Yakutia), Russian Federation

${ }^{3}$ Research Institute of Regional Economy of the North, North-Eastern Federal University in Yakutsk Republic of Sakha (Yakutia), Russian Federation Yakutsk Sakha-Yakutia, 677007, Russia, E-mail: sImnvm@mail.ru, suruktsg@gmail.com
\end{abstract} \\ Correspondence: Department of Construction Economics and Housing, Research Institute of Regional Economy of the North \\ North-Eastern Federal University in Yakutsk, Republic of Sakha (Yakutia), Russian Federation, 2 Petrovsky Street, office 306
}

\section{Doi:10.5901/mjss.2015.v6n5s4p473}

\section{Abstract}

The article proves the need for reforming the housing and utilities sector (HUS) on the example of Sakha Republic (Yakutia) aimed at improving its performance as a basis for raising standard of living of the local population and effectiveness of reproduction processes in northern regions of Russia. On the basis of attributive estimation of the current state of HUS of Sakha Republic (Yakutia) the critical state of operation of the sector over the period of 2000-2014 is grounded. It is determined that HUS is characterized by low quality and limited range of housing and utilities services provided to the population, which is due to high wear-out rates of technical infrastructure and weak operational capacities of HUS. It is pointed out that the region's HUS is unprofitable and operates in the environment of permanent shortage of funds due to unsatisfying payment discipline of the population and its low level, insufficient state funding. Systematic lack of funds is proven to be a key factor, which constrains technical modernization of utilities infrastructure of the region's HUS and further reduces its profitability. The research proposes a system of measures aimed at improving reproduction functions of HUS of Sakha Republic (Yakutia) as three optimization areas of reforms: expansion of financial potential and improvement of management effectiveness in HUS, reconstruction and technical modernization of the engineering complex of HUS. Practical implementation of the proposed conceptual measures will become a prerequisite for securing financial stability and raising the sector's competitiveness, which, eventually, will contribute to raising standard of living of the population under critical natural and climatic conditions and boosting economic potential of the northern regions.

Keywords: housing and utilities sector, utilities charges, housing and utilities services, technical infrastructure of HUS, housing stock, HUS reforming

\section{Introduction}

\subsection{Introduction of the Problem}

The Sakha Republic (Yakutia) is one of the largest subjects of the Russian Federation located in the north-eastern part of the country. Over $40 \%$ of its territory lies beyond the Polar circle, which is the reason why Yakutia is the coldest habitable region on the Earth, with a severely continental climate, long winter periods and short summer periods (Official information portal of Sakha Republic (Yakutia), 2015). Due to social and economic problems aggravated by the region's harsh climate, it would be reasonable to compensate unfavorable climatic conditions by providing a higher standard of living, which calls for improving performance of housing and utilities sector (HUS) of Sakha Republic (Yakutia). In the context of the harsh climate, HUS is one of the leading industries of social and economic importance in the republic, because it is aimed at providing the required conditions for normal human activity, creating working conditions at enterprises (providing heat, power, water, etc.), urban development, etc. Therefore, effective HUS is the most important 
factor in development of material production and reproduction of labor force in the region.

\subsection{Importance of the Problem}

Significant drawbacks in a rate-setting system, low growth rates of housing construction, housing stock dominated by houses in critical or wrecked state, low quality of utility services, and a number of other unsolved problems surrounding material production and labor force reproduction in the Sakha Republic (Yakutia) call for reforming of HUS by the republic's government in order to improve its performance. In the present context, reforming and functional optimization of HUS development is the most important area of social and economic transformation in the republic and the way of raising standard of living of the local population. This predetermines relevance and timeliness of scientific priority in researches of the current state, tendencies, and prospects of HUS development within the process of boosting economic potential of Sakha Republic (Yakutia) as a region with critical living conditions.

\subsection{Relevant Scholarship}

Analysis of the findings of the leading researchers and specialized literature demonstrates deep theoretical knowledge of the issues surrounding improvement of performance of housing and utilities sector within the state concept of reforming. A significant contribution to studying theoretical aspects and basic concepts of operation of housing and utilities sector as a factor in reproduction processes was made by such academics as: E. Agitaev (2010), S. Bykova (2012), D. Volodin (2013), P. Evseenko (2014), A. Ivanov (2011), T. Klebanova (2015), O. Rudachenko (2015), M. Privezentsev (2012), 0. Skripnik (2013), O. Timchuk (2011), M. Shevchenko (2013), D. Frolov (2013), S. Chernov (2014), M. Kerry (2009), B. Lachman (2011), F. Lewis (2009), J. Ransby-Sporn (2011), etc.

Special features that characterize housing and utilities sector operating in severe natural and climatic conditions were researched by the following academics: G. Zaripova (2014), A. Kolodeznikov (2013), A. Pytkin (2014), M. Solomonov (2013), V. Tikhonov (2011), R. Gunnarsdottir (2013), P. Marin (2009), A. Vanamali (2015), etc.

Nevertheless, scientific accomplishments and accumulated practical experience in the topic discussed still leave open both theoretical and practical aspects of its solution, which require further research. In particular, the issues surrounding development of approaches and determination of the current priority areas of reforming housing and utilities sector under harsh natural and climatic conditions, in the context of insolvency of utility companies and low quality of housing and utilities services provided to the population.

\subsection{State Hypotheses and Their Correspondence to Research Design}

Due to discussions and ambiguity of conceptual approaches to this scientific field, the goal of this research is to develop theoretical and conceptual guidance on improving performance of HUS based on analysis of the current state and to determine special features of that socially-orientated sector of economy on the example of Sakha Republic (Yakutia)-a northern region of the Russian Federation.

The research addresses a number of conceptual issues:

- An analysis of the current state and capacities of technical infrastructure of the Republic's HUS over the 20002014 period;

- An estimation of financial stability of housing and utilities companies and quality of services provided by them to the population;

- Determination of the key factors derailing development of HUS of Sakha Republic (Yakutia);

- A description of the key promising areas of HUS reforming aimed at improving its performance.

\section{Method}

To achieve the goal and solve the conceptual tasks, general scientific and specialized methods were used.

\subsection{Method of Statistical Survey}

By using a sample statistical survey, a source database was formed in order to estimate the current state of HUS in the Sakha Republic (Yakutia) over the 2000-2014 period. Collected data on indicators of housing stock development, heat supply, water supply, and sewage system in the region allowed to creating the analytic base for an estimation of technical 
state of utilities infrastructure of HUS. Classification of quantity data on the structure of income and expenses of housing and utilities companies over the studied period allowed to generate an array of information to estimate the financial state of the sector. Collection of quality information on legal forms of housing and utilities companies served as a basis for attributive estimation of management effectiveness.

\subsection{Methods of Analysis and Measurement}

Based on the statistical sample of quantity data on development of housing stock, heat supply, water supply, and sewage system, structure of income and expenses of housing and utilities companies, a dynamic row of relative indicators characterizing the state of technical infrastructure of HUS in the Sakha Republic (Yakutia) over 2000-2014 and the financial state of utilities companies was built by using statistical measurement. That information sample allowed to estimate the current state of HUS and determine the factors that weaken its effectiveness.

\subsection{Empirical Approach of Scientific Cognition}

Detailed study and monitoring of dynamic quantity indicators characterizing development of housing stock, heat supply, water supply and sewage system, financial potential and effectiveness of management in HUS of Sakha Republic (Yakutia) allowed to determine quality criteria for special features of the sector. Using a method of scientific generalization of the current state of the studied object and method of logical cognition, conceptual guidance on improving performance of HUS in the northern region was developed.

\section{Results}

Housing and utilities sector is a sector of a local self-governing economy that embraces a complex of economic relations arising from the process of production and providing chargeable housing and utilities services to the population and other subjects of economy.

At the current stage of development of the country's northern regions, the housing and utilities complex is one of the most socially significant economic sectors. The general tendency of HUS development in the northern regions of Russia (in the Sakha Republic (Yakutia), in particular) complies with the general strategy of HUS development in Russia and the concept of social and economic development of the state (Concept of long-term social and economic development of the Russian Federation till 2020, 2009), (Draft strategy for development of housing and utilities sector in the Russian Federation till 2020, 2015). The strategic long-term goal of state policy in housing and utilities sector till 2020 consists in building a favorable environment for human living and activities that would allow to solve not only housing problems, but also provide a high standard of living in general. This concept is especially relevant for regions with complex and uncomfortable climatic conditions, including the Sakha Republic (Yakutia).

Although the housing and utilities infrastructure of Sakha Republic (Yakutia) constitutes a significant share in the national wealth of the region, the current state of HUS fails to keep up with its technological and economic potential. For example, despite a rather lengthy period of HUS reforming aimed at improving its performance, this sector is the most unprofitable area of activity not only in the Sakha Republic (Yakutia), but also in the Russian Federation in general (Skripnik, 2013).

HUS of Sakha Republic (Yakutia) is based on the multi-apartment housing stock, which as of beginning of 2015 was estimated at 12403.2 thousand sq.m., with 580.1 thousand people living there. As most part of the hosing stock was built in late 50 s-early 90 s of the last century, almost $4 \%$ (475.13 thousand sq. m.-1466 houses) of houses are in critical condition and are subject to demolition after resettlement of its residents. (State corporation-HUS Reform Foundation, 2015). In addition, as of early 2015 , the republic's average wear rate of housing stock was estimated at $60 \%$. The current standards set the need for annual capital repairs of housing stock at up to $20 \%$, while every year only about $2 \%$ houses are repaired in the region (Agitaev, 2010; Housing Code of the Russian Federation, 2014).

Based on indicators characterizing housing stock development by main types of utilities, the Sakha Republic (Yakutia) is below the national average (On the brink of catastrophe: Russian HUS in figures, 2015). According to the data from Table 1, slighly more than half of houses in the region are equipped with water pipeline and a water disposal system. As of late 2014 , less than $30 \%$ of houses have electrical stoves or gas supply, $73.8 \%$ have a central heating system and less than $50 \%$ have a bathtub or a shower.

Housing stock must function in tight interaction with the technological complex of HUS. The complex relies on utilities infrastructure (boilerhouses, networks, water intake structures, sewage treatment facilities, pumping houses, etc.) 
which is currently characterized by high wear-out rate, low efficiency, critical state, and substantial energy consumption (Solomonov \& Kolodeznikov, 2013; Lewis, 2009; Ransby-Sporn, 2011).

Table 1. Indicators of housing stock development in Sakha Republic (Yakutia)

\begin{tabular}{lccccccccc}
\hline Indicators & 2002 & 2005 & 2007 & 2009 & 2010 & 2012 & 2013 & 2014 \\
\hline Percentage of total housing area with water pipelines & 52.1 & 53.2 & 53 & 53.2 & 53.3 & 53.4 & 52.8 & 52 \\
Percentage of total housing area with sewage systems & 49.6 & 51.4 & 51.6 & 51.9 & 52.3 & 52.9 & 51.1 & 50.7 \\
Percentage of total housing area with central heating & 65.7 & 64.6 & 63.4 & 63.7 & 63.8 & 74.5 & 74.4 & 73.8 \\
Percentage of total housing area with bathtubs (showers) & 47.5 & 49.5 & 50 & 50.4 & 50.7 & 50.8 & 48.5 & 48.3 \\
Percentage of total housing area with gas supply (pipeline gas, liquid gas) & 21.3 & 23.9 & 25.2 & 27.2 & 28.3 & 29.7 & 29.3 & 28.6 \\
Percentage of total housing area with floor electric stoves & 27.8 & 28.1 & 28 & 27.1 & 27 & 27.8 & 29 & 29 \\
\hline
\end{tabular}

Description: Composed by the authors using the following materials (Housing and utilities sector of Sakha Republic

(Yakutia), 2014; Website of Ministry of housing, utilities, and energy of Sakha Republic (Yakutia), 2015; Website of Territorial agency of Federal statistical service of Sakha Republic (Yakutia), 2015).

Strong positive dynamics of the indicators further aggravate unsatisfying current state of utilities infrastructure of Sakha Republic (Yakutia). Over the last 12 years, capacities of boilerhouses increased only by 8.7\%, and since 2012 the tendency has had a negative dynamics-compared with 2002, it decreased almost by $9 \%$ (Figure 1).

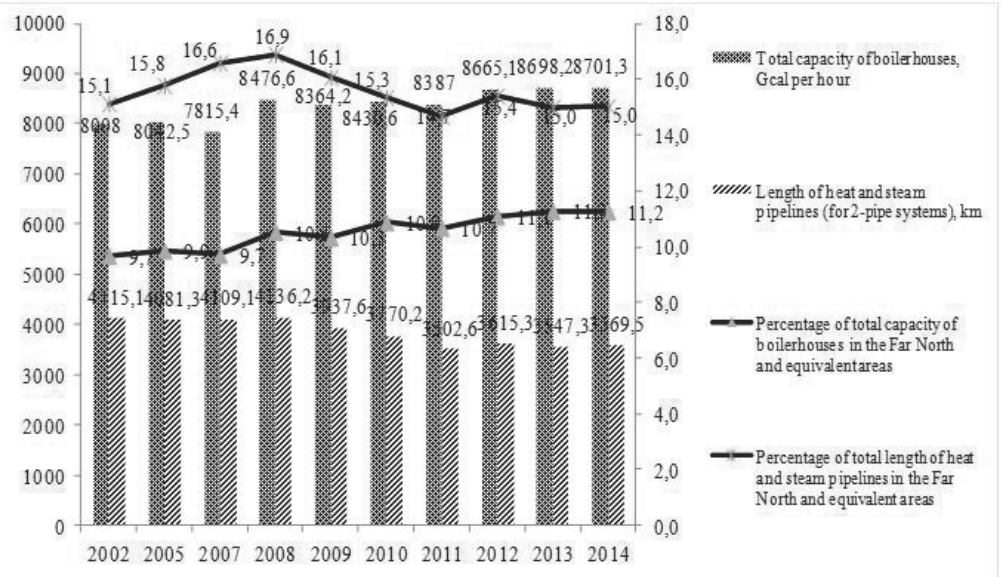

Figure 1. Indicators characterizing heat supply in Sakha Republic (Yakutia)

Description: Composed by the authors using the following materials (Housing and utilities sector of Sakha Republic (Yakutia), 2014; Website of Ministry of housing, utilities, and energy of Sakha Republic (Yakutia), 2015; Website of Territorial agency of Federal statistical service of Sakha Republic (Yakutia), 2015).

Over the studied period, insignificant growth has been registered in capacity of water pipelines-compared to 2002, in 2014 it increased by $6 \%$, while the length of water pipelines decreased by $1 \%$ (Figure 2). In addition, dynamic indicators of water supply development in Sakha Republic (Yakutia) slow down their growth, which points out dwindling opportunities to improve quality of water supply in the region in the near future. 


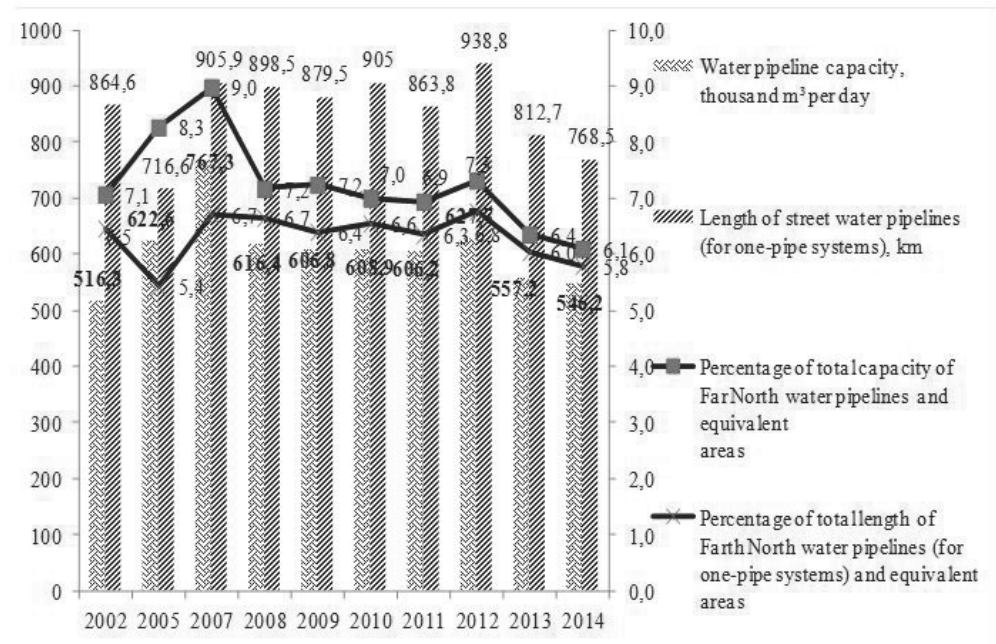

Figure 2. Indicators characterizing water supply in Sakha Republic (Yakutia)

Description: Composed by the authors using the following materials (Housing and utilities sector of Sakha Republic (Yakutia), 2014; Website of Ministry of housing, utilities, and energy of Sakha Republic (Yakutia), 2015; Website of Territorial agency of Federal statistical service of Sakha Republic (Yakutia), 2015).

Sewage treatment systems are also characterized by decreasing quality: Over the last 12 years, their performance fell by $12 \%$, despite a $26.7 \%$ increase in their length and positive dynamics of kinetic indicators of sewage system development in the region (Figure 3).

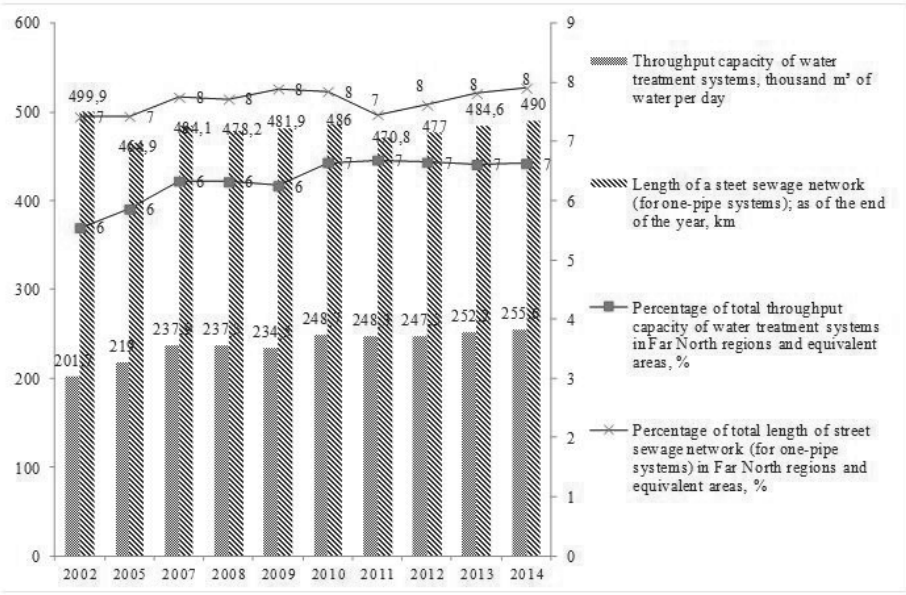

Figure 3. Indicators of sewage system development in Sakha Republic (Yakutia)

Description: Composed by the authors using the following materials (Housing and utilities sector of Sakha Republic (Yakutia), 2014; Website of Ministry of housing, utilities, and energy of Sakha Republic (Yakutia), 2015; Website of Territorial agency of Federal statistical service of Sakha Republic (Yakutia), 2015)

In the context of low capacities, the technological fund of the region has up to $60 \%$ wear-out rate, which results in the 
critical state of sewage, water supply, and heat supply networks.

The research determined that $92.65 \%$ of total expenses of utilities companies in the Sakha Republic (Yakutia) accounts for maintenance and servicing of the housing stock and production facilities of utilities infrastructure (Figure 4).
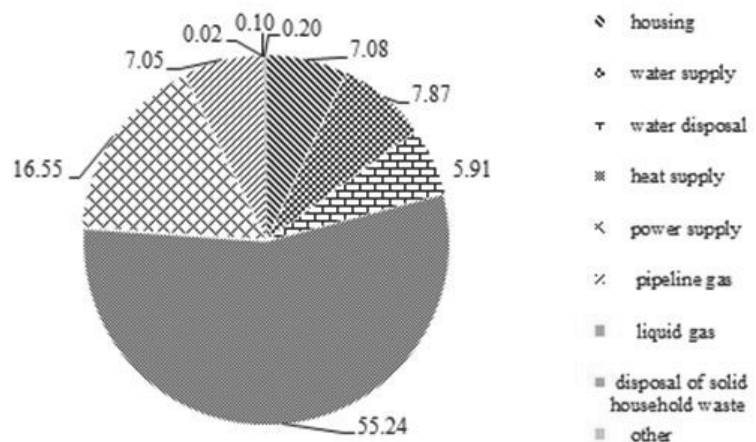

Figure 4. Structure of expenses of housing and utilities companies in 2014 (in \%)

Description: Composed by the authors using the following materials (Housing and utilities sector of Sakha Republic (Yakutia), 2014; Website of Ministry of housing, utilities, and energy of Sakha Republic (Yakutia), 2015; Website of Territorial agency of Federal statistical service of Sakha Republic (Yakutia), 2015)

Utilities charges are a main source of income of housing and utilities companies. However, low utilities charges and insufficient external funding of HUS make the prospects of modernizing and upgrading the technological complex of HUS extremely vague.

One of areas of the general strategy of reforming HUS in the Russian Federation is a significant increase of utilities charges for the population as a basis for modernization of the sector's facilities and improving profitability of utilities companies (Bykova, 2012; About the measures on improving the quality of housing and utilities services, 2013).

According to statistical data, over the last 12 years charges for housing and utilities services have grown significantly and demonstrate an uptrend. For example, as of 2014, charges for housing in state or municipal houses increased by 5,9 times compared to 2000 ; electricity charges by 7,8 times, water and sewage charges—by 10,5 times; hot water charges-by 31.8 times; (Figure 5).

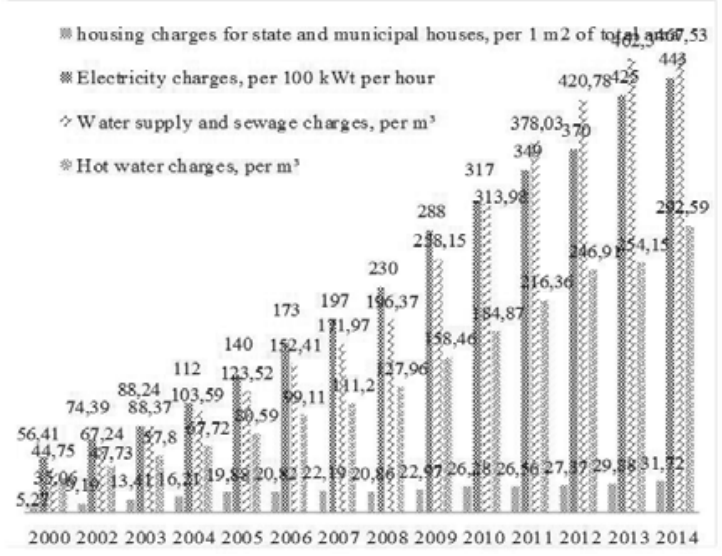

Figure 5. Average rates for housing and utilities in Sakha Republic (Yakutia), rub. for one kind of services 
Description: Composed by the authors using the following materials (Housing and utilities sector of Sakha Republic (Yakutia), 2014; Website of Ministry of housing, utilities, and energy of Sakha Republic (Yakutia), 2015; Website of Territorial agency of Federal statistical service of Sakha Republic (Yakutia), 2015; Rates for HUS services: Questions and Answers, 2013).

Central heating charges grew significantly: over the 2000-2014 period, they increased by 9 times and gas charges—by 10 times (Figure 6).

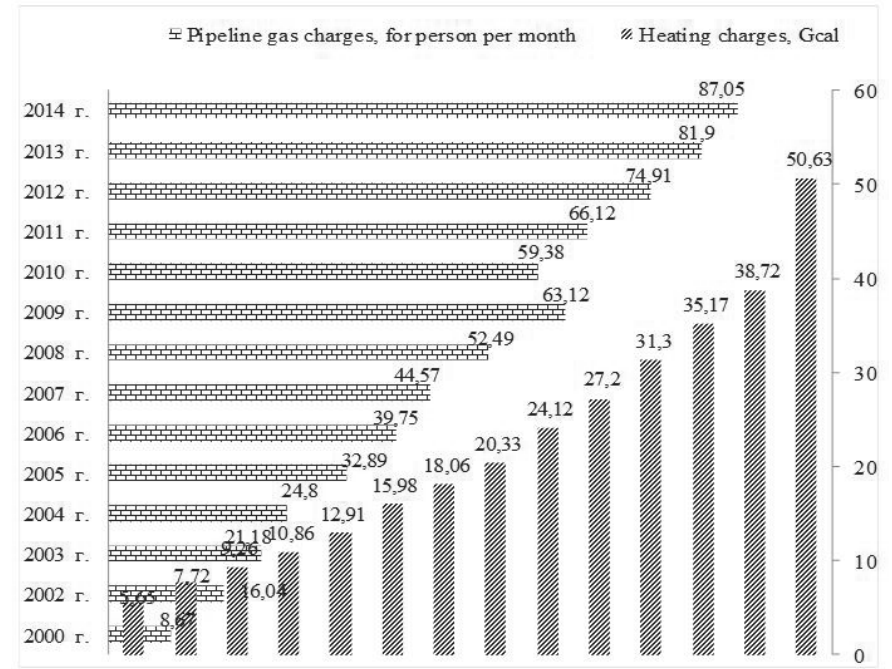

Figure 6. Average heating and gas rates for population, rub. for one kind of services

Description: Composed by the authors using the following materials (Housing and utilities sector of Sakha Republic (Yakutia), 2014; Website of Ministry of housing, utilities, and energy of Sakha Republic (Yakutia), 2015; Website of Territorial agency of Federal statistical service of Sakha Republic (Yakutia), 2015; Rates for HUS services: Questions and Answers, 2013).

In the context of practically unchanged technological infrastructure of HUS in the Sakha Republic (Yakutia), growing utilities rates fail to solve financial problems of utilities companies, and therefore, fail to provide funds for reconstruction and modernization of the sector's facilities.

Despite growing financial turnover of HUS from providing utilities services (+233\% as of 2014 compared to 2000), incomes fail to fully cover expenses (Figure 7).

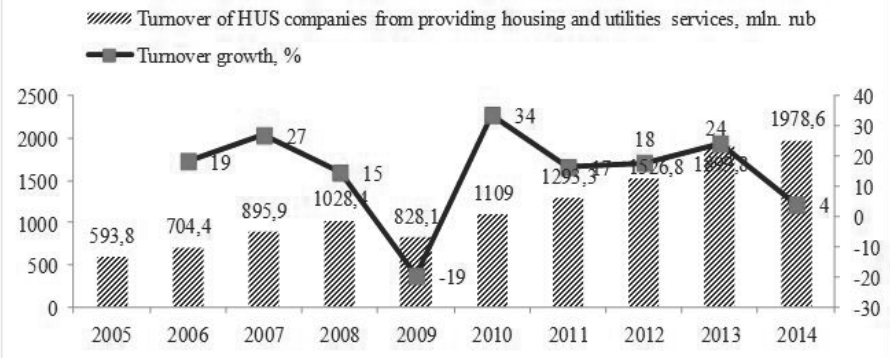

Figure 7. Turnover of HUS organizations from providing utilities services 
Description: Composed by the authors using the following materials (Housing and utilities sector of Sakha Republic (Yakutia), 2014; Website of Ministry of housing, utilities, and energy of Sakha Republic (Yakutia), 2015; Website of Territorial agency of Federal statistical service of Sakha Republic (Yakutia), 2015)

In 2014, the total amount of utilities fees charged from the population was 2675346.5 thousand rubles, which accounts for $79 \%$ of the total income of HUS of Sakha Republic (Yakutia) and covers only $68 \%$ of expenses of HUS companies (Website of Territorial agency of Federal statistical service of Sakha Republic (Yakutia), 2015). The amount of money required by the companies to implement their main activities is $81 \%$ of the total amount of expenses. Insufficient funding of utilities companies of the region results in the deficit of 262200.5 thousand rubles arising from low profitability of HUS and slackening increment rates of the turnover from providing utilities services (in 2014, the increment rate amounted to $4 \%$ compared to $19 \%$ in 2006) (Figure 7). The main reason of unsatisfying financial state of utilities companies in the Sakha Republic (Yakutia) is a low level of utilities rates for the population accompanied with large arrears in payments for utilities services. As of the end of 2014 , the total amount of accounts receivable by utilities companies of the region was 1060652.9 thousand rubles, $85.8 \%$ of which accounted for arrears in payments for utilities services by the population, which, in its turn, is almost $30 \%$ of the total income of the republic's HUS.

A low level of the population's discipline in paying for housing and utilities services in the Sakha Republic (Yakutia) is accounted for a low paying capacity of the majority of people. Over the 2005-2014 period, a share of housing and utility costs in consumer expenses increased up to $16.2 \%$, i.e., grew by $6.5 \%$, which is explained by increased heat supply rates mentioned above (Figure 8).

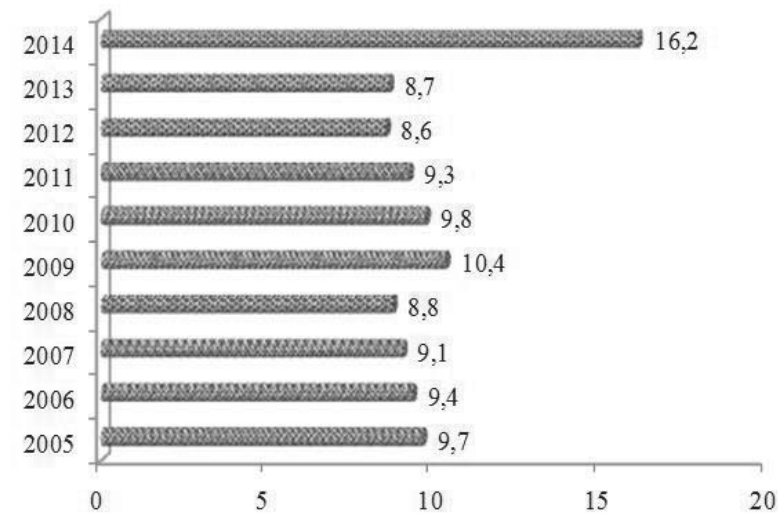

Figure 8. Share of housing and utilities costs in the total amount of consumer expenses of the population in Sakha Republic (Yakutia), \%

Description: Composed by the authors using the following materials (Website of Territorial agency of Federal statistical service of Sakha Republic (Yakutia), 2015).

Payment capacity of the population in relation to utilities services dropped by the end of 2014 . Although during the last 14 years it showed a quite stable dynamics, today it is characterized by decreasing share of timely payments for housing and utilities services and accumulating arrears (Figure 9). 


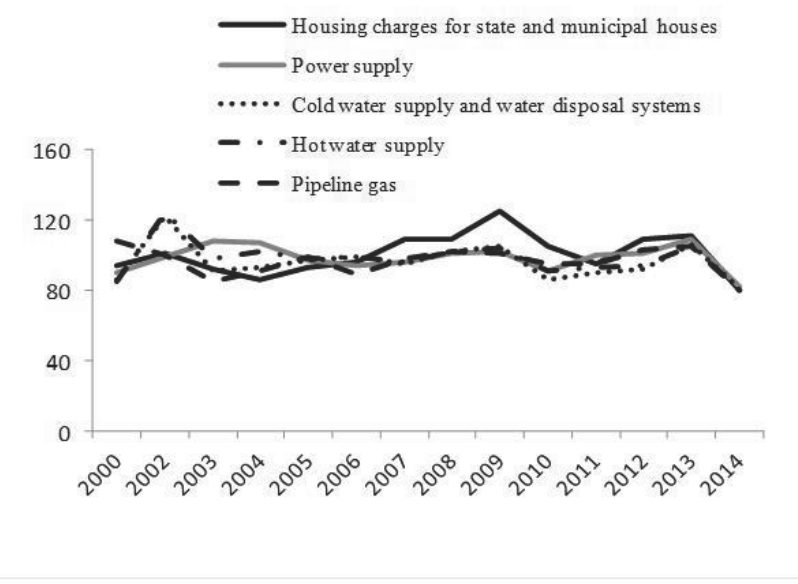

Figure 9. Payment capacity of per capita income of population of Sakha Republic in relation to chargeable utilities services, in \% compared to previous year

Description: Composed by the authors using the following materials (Housing and utilities sector of Sakha Republic (Yakutia), 2014; Website of Ministry of housing, utilities, and energy of Sakha Republic (Yakutia), 2015; Website of Territorial agency of Federal statistical service of Sakha Republic (Yakutia), 2015).

Based on the analysis, it must be noted that the paying capacity of the population in relation to housing and utility services does not correlate with the level of allowances granted to the citizens of Sakha Republic (Yakutia).

According to the data in Figure 10, a more than five-fold increase of the total amount of allowances granted by HUS companies over the 2000-2014 period was not accompanied by increase in paying capacity. As of beginning of 2015, the total amount of payments for housing and utilities services issued to the population was 3182560.4 thousand rubles, while the amount of received payments totaled just $84.1 \%$ of that sum. Thus, even when the amount of allowances is around $63 \%$ of the amount of payments issued for housing and utilities services, HUS organizations of Sakha Republic (Yakutia) receive less income than planned in the form of utilities charges.

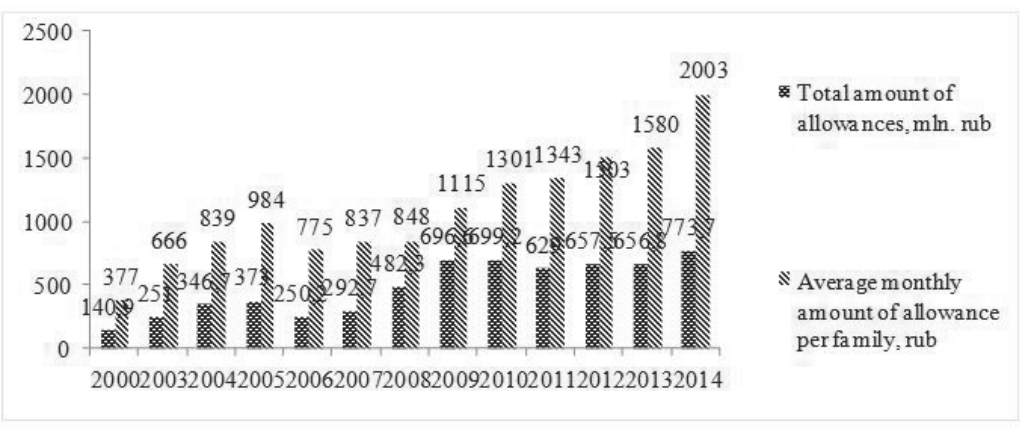

Figure 10. Dynamics of housing and utilities allowances

Description: Composed by the authors using the following materials: (Website of Territorial agency of Federal statistical service of Sakha Republic (Yakutia), 2015)

In the context of constant lack of funds and low level of state funding (2.9\% of the total income of HUS), allocations for maintenance and modernization of the technological infrastructure of HUS in the Sakha Republic (Yakutia) are rather 
symbolic (On the brink of catastrophe: Russian HUS in figures, 2013). According to the statistical data as of 2015, expenses of HUS companies on depreciation amounted to 5.3\% (2904.2 mln rubles), and expenses on repair fund and repair and technical maintenance totaled 4.7\% (2 602.4 mln rubles) (Website of Territorial agency of Federal statistical service of Sakha Republic (Yakutia), 2015). In addition, almost all housing and utilities companies of the region operate as municipal unitary enterprises characterized as uncompetitive economic entities in the market with ineffective managerial functions, which, in its turn, further reduces profitability and investment appeal of that socially important economic sector of Sakha Republic (Ivanov, 2011; Solomonov and Tikhonov, 2011; Privezentsev et al., 2012). In this connection, in the context of harsh climatic conditions, improvement of quality of utility services provided to the population is a top-priority task in the current social and economic policy of the government of Sakha Republic (Yakutia).

\section{Discussion}

Analysis of the current state and special operational aspects of HUS of Sakha Republic (Yakutia) over the 2000-2014 period gives reasons to state that weak financial viability of HUS is mostly due to unprofitability of utilities companies. This tendency pre-determines the top-priority task of reforming the region's HUS, which consists in securing financial stability of HUS. Solving the issue of financial stability of housing and utilities sector in conformity with and accompanied by effective management will allow to establish the base for modernization, reconstruction, and technical upgrading of the sector's utilities infrastructure, which is a key factor in effective performance of HUS in severe climatic environment (Volodin, 2013; Shevchenko \& Frolov, 2013; Kerry, 2009).

The research proposes a system of measures aimed at reforming the housing and utilities sector of Sakha Republic (Yakutia). These measures are expected to create prerequisites for improving HUS performance and fulfilling its potential as a life-support system (Figure 11).

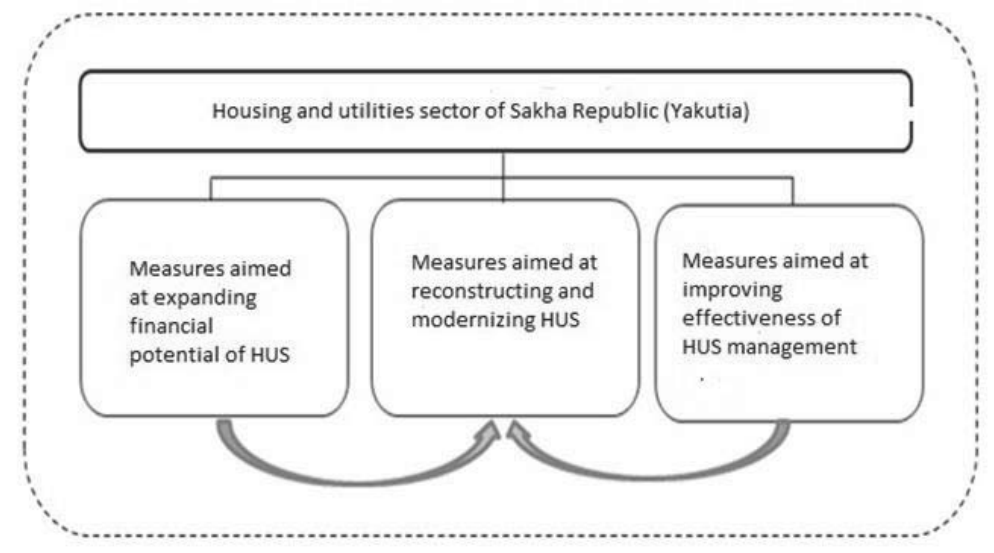

Figure 11. Main areas of reforming HUS in Sakha Republic (Yakutia)

Expansion of financial base of utilities companies includes the following complex of optimization measures:

- Development and introduction of a system of measures aimed at improving the discipline of payment for provided housing and utilities services;

- Bringing the denoted level of payment of utility bills by citizens with the maximum possible part of their own costs of the population in the total volume of family income according to social norms for residential areas and consumption standards of public services;

- Introduction of system of full payment for provided housing and utilities services for the citizens that have a second house/flat or whose living space exceeds the social standards applied in the republic;

- Limitation aimed at complete eradication of cross-subsidization of utilities services;

- Effective management of accounts payable and receivable by utilities companies by drawing up an inventory of and restructuring debt obligations; 
- Increasing investment appeal of housing and utilities companies;

- Development and implementation of effective investment strategies in HUS operation;

- Formation of long-term borrowed capital on favorable credit terms or according to means of financial assets;

- Introduction of state-of-the-art systems that keep record of and regulate consumption by the population of natural gas and heat, hot and cold water;

- Improving performance of financial and economic mechanisms of production, consumption, and transportation of energy resources, etc.

In the context of toughening competitiveness of organization structure of HUS, the following optimization managerial measures must become priority of reforming HUS of Sakha Republic (Yakutia):

- Re-organization of legal form of housing and utilities companies from unitary enterprises to OJSC, which will allow to raise their competitiveness;

- Introduction of concession practice, while keeping all objects of network utilities infrastructure in municipal property;

- Establishment of competitive environment in HUS through differentiation of client and contractor functions in the process of providing housing and utilities services and introduction of practice of contract relations between contactors and governing organizations and homeowners;

- Establishment of centers for making settlements of utilities charges in order to accumulate and collect the fullest information about the flow of payments made by consumers of housing and utilities services;

- Introduction of a rigid system of state control over quality and volumes of housing and utilities services provided to the population and use of house stock;

- Establishment and introduction of such organization structures as a homeowner association within a single housing complex as a means of effective protection of rights of homeowners.

- As the Sakha Republic (Yakutia) is a region with severe climatic conditions with long winter periods, in the process of HUS optimization special attention must be paid to expansion of capacities of technological complex of sector based on the following system of measures:

- Modernization, reconstruction, and technical upgrading of engineering infrastructure aimed at improving its performance in operating mode;

- Introduction of state-of-the-art innovative and energy and resource saving technologies to the engineering infrastructure of HUS;

- Promotion of energy efficiency of reconstructed facilities, along with other resource-efficient measures;

- Use of high-quality and reliable building constructions and materials and elements of engineering systems for operation, reconstruction, and repair of public and housing premises, which will allow to significantly increase their energy efficiency and reduce operation costs in the long-term (Lachman, 2011; Warren et al., 2006);

- Introduction of autonomous heating and heat systems, etc.

- Introduction and implementation of conceptual optimization measures within the main areas of reforming HUS in the Sakha Republic (Yakutia) will become the basis for re-evaluation of the sector's competitiveness and create prerequisites for improving the quality and standards of housing and utilities services provided to the population. HUS effectiveness will result in the increased standard of living, which is a key factor in reproduction processes in the region.

\section{Conclusion}

Based on the analysis of the current state of the housing and utilities sector of Sakha Republic (Yakutia), one can conclude its critical state over the studied period. It is characterized by low quality and limited range of housing and utilities services provided to the population, which is accounted for the high wear-out rate and low capacity of the sector's facilities. Due to low paying capacity of the population for housing and utilities services and insufficient state funding, HUS of the republic is unprofitable and operates in the environment of permanent shortage of funds. Permanent shortage of funding excludes the opportunities for modernization of the technological system of HUS of Sakha Republic (Yakutia), which further decreases profitability of HUS.

In order to reform HUS and improve its performance, a system of three areas of optimization measures was proposed in the research: the expansion of financial potential and the improvement of management effectiveness, the reconstruction and the technical modernization of the sector's technological complex. The practical implementation of the proposed conceptual measures will create prerequisites for financial stability and improvement of competitiveness aimed 
at raising the quality of housing and utilities services provided to the population. As the quality of the services is a factor influencing reproduction processes, this creates the theoretical basis for further scientific researches in this field.

\section{References}

About measures for improving the quality of housing and utilities services. (2013). Report by the State Council (p. 97). Saint-Petersburg, Agitaev, E. V. (2010). New concept of reforming HUS, JKH. Ekonomika i upravlenie predpriyatiem JKH (pp. 3-9). Moscow, Russia.

Bykova, S. A. (2012). Housing stock and complete repairs services for the population. About criteria for housing and utilities services provided to the population. Rossiyskoe Predprinimatelstvo (pp. 137-141). Moscow, Russia.

Concept of long-term social and economic development of the Russian Federation till 2020 (Decree of the Government of the Russian Federation, p. 1662). (2009). Retrieved from http://www.consultant.ru/document/cons_doc_LAW_90601/?frame=1

Draft strategy for housing and utilities sector development in the Russian Federation till 2020. (2015). Retrieved from http://ruscpo. $\mathrm{ru} / \mathrm{p}=10041$

Galezhenko, O. N. (2012). Problems of HUS operation during reforming. Vestnik Volgogradskogo gosudarstvennogo universiteta (pp. 121-127). Volgograd, Russia.

Gunnarsdottir, R. et al. (Eds.). (2013). A review of wastewater handling in the Arctic with special reference to pharmaceuticals and personal care products (PPCPs) and microbial pollution. Ecological Engineering (Vol. 1, pp. 76-85).

Evseenko, P., \& Chernov, S. (2014). Estimation of potential of expanding energy efficiency in HUS. Monograph. LAP Lambert Academic Publishing (p. 120).

Housing and utilities rates: Questions and answers. (2013). Voprosy mestnogo samoupravlenia (Vol. 1, pp. 92-95). Moscow, Russia.

Housing and utilities sector of Sakha Republic (Yakutia). (2014). Statistical book (p. 88).

Housing code of the Russian Federation. (2014). Retrieved from http://www.consultant.ru/popular/housing/

Ivanov, A. R. (2011). Housing and utilities sector (HUS): Problems and ways of addressing them. Biznes v zakone. Economikouridicheskiy zhurnal (pp. 197-198).

Kerry, M. (2009). Exploratory Analysis in the Utility of Logistics Planning. Software to Logistics Planners at the Division Simon and Schuster (p. 100).

Khairullina, V. G. et al. (Eds.). (2014). System approach to solving problems of HUS. Vestnik UGUES. Nauka, obrazovanie, ekonomika (Vol. 1, pp. 42-45). Ufa, Russia.

Klebanova, T. S., \& Rudachenko, O. A. (2015). Predicting financial indicators of a housing and utilities company by using adaptive models, Business Inform (pp. 143-148). Kharkiv, Ukraine.

Kotomin, A. B. (2011). Ways and problems of energy-efficient development of HUS in the northern regions of Russia based on innovative technologies. Ekonomicheskie i sozialnye problemy: Facty, tendentsii, prognoz (Vol. 18, pp. 66-76). Vologda, Russia.

Lachman, B. E. (Eds.). (2011). Making the Connection Beneficial Collaboration Between Army Installations and Energy Utility Companies. ARROYO CENTER (p. 156).

Lewis, F. (2009). Fort Lewis Executive Summary. Five Year Plan: Sustainability Implementation Plan (p. 537) Washington.

Marin, P. (2009). Public-private partnerships for urban water utilities: A review of experiences in developing countries (p. 206). Washington D. C.: The World Bank. Retrieved from http:// http://elibrary.worldbank.org/doi/pdf/10.1596/978-0-8213-7956-1

Official information portal of Sakha Republic (Yakutia). (2015). Retrieved from http://www.sakha.gov.ru/

On the brink of catastrophe: Russian HUS in figures. (2013). Retrieved from http://xn----gtbhmt7a0dva.xn--p1ai/information/ news/show/item/103/

Privezentsev, M. V. et al. (Eds.). (2012). Managing investment processes in urban HUS: Organization and economic regulation (Monograph, p. 367). UNITI-DANA.

Pytkin, A. N., \& Zaripova, G. M. (2014). Current aspects of reforming HUS. Vestnik UGUES. Nauka, obrazovanie, ekonomika (pp. 5359). Ufa, Russia.

Ransby-Sporn, J. (2011). Engaging as Partners in Energy Efficiency: Multifamily Housing and Utilities. Retrieved from http://www.aikencolon.com/ assets/ images/pdfs/lECC/florida/a122.pdf

Shevchenko, M. V., \& Frolov, D. V. (2013). Problems of reforming housing and utilities system and alternative changes. KANT, 1(7), 2531.

Skripnik, O. B. (2013). Reforming regional housing and utilities sector: Methodology and practice (p. 288). Moscow: Financy i statistika.

Solomonov, M. P., \& Kolodeznikov, A. S. (2013). Methodological approaches to studying innovative development of housing and utilities sector in the North. Ekonomicheskiy analiz: Teoriya i praktika (pp. 17-22). Moscow, Russia.

State corporation-HUS reform foundation. (2015). Retrieved from http://www.fondgkh.ru/reforma/index.html

Timchuk, O. G. (2011). Main areas of HUS development in the Russian Federation. Relevant economic and management issues: Materials from international scientific conference (pp. 245-248). Moscow: RIOR,.

Unturbe, J. M. (2013). Introduction the importance of water cooperation. Water cooperation (p. 100).

Vanamali, A. (2015). 5 ways utilities can lead on climate goals. Retrieved from http://www.greenbiz.com/article/5-ways-utilities-can-leadclimate-goals

Volodin, D. (2013). HUS in the need of precise state policy. BOSS. Biznes: Organizatsii, strategii, sistemy (pp. 33-41).

Warren, J. (1996). American Society of Civil Engineers. ASCE Cold Regions Utilities Monograph (p. 780).

Warren, J. A. et al. (Eds.). (2006). Climate change and human health: infrastructure impacts to small remote communities in the north. 
International journal of circumpolar health (pp. 87-97).

Website of Ministry of housing, utilities and energy of Sakha Republic (Yakutia). (2015). Retrieved from http://www.sakha.gov.ru/minjkh Website of Territorial agency of Federal statistical service for Sakha Republic (Yakutia). (2015). Retrieved from http://sakha.gks.rul Website of Federal statistical service. (2015). Retrieved from http://www.gks.rul 